\title{
Nie-egte vrae in 1 Korintiërs 5-6
}

\author{
Author: \\ Andreas H. Snyman ${ }^{1}$ \\ Affiliation: \\ ${ }^{1}$ Department New Testament, \\ University of the Free State, \\ Bloemfontein, South Africa \\ Correspondence to: \\ Andries Snyman \\ Email: \\ ahsnyman44@gmail.com \\ Postal address: \\ PO Box 29084, Danhof 9310 \\ South Africa \\ Dates: \\ Received: 08 Feb. 2011 \\ Accepted: 23 June 2011 \\ Published: 14 Dec. 2012 \\ How to cite this article: \\ Snyman, A.H., 2012, 'Nie- \\ egte vrae in 1 Korintiërs 5-6', \\ In die Skriflig/In Luce Verbi \\ 46(2), Art \#68, 8 pages. \\ http://dx.doi.org/10.4102/ \\ ids.v46i2.68
}

C 2012. The Authors. Licensee: AOSIS OpenJournals. This work is licensed under the Creative Commons Attribution License.
In tradisionele grammatikas en kommentare word gewoonlik net onderskei tussen egte en retoriese vrae. In hierdie artikel word nie-egte vrae geklassifiseer aan die hand van 'n model wat ontwikkel is uit die taalhandelingsteorie. In plaas van alle nie-egte vrae as retoriese vrae te beskou (soos die meeste kommentators doen), maak die model voorsiening vir ses hoof- en verskeie subkategorieë van nie-egte vrae. Die model word kortliks opgesom, gevolg deur ' $n$ sistematiese ondersoek van al die vrae in 1 Korintiërs 5-6. Die slotsom is dat die voorgestelde model nuttig is vir die onderskeiding van verskillende soorte nie-egte vrae binne 'n wetenskaplike raamwerk en vir die bepaling van hulle kommunikatiewe funksies. Op dié wyse word ' $n$ bydrae gelewer tot die vertaling en eksegese van die betrokke gedeeltes. Die model behoort navorsing oor die rol van nie-egte vrae in al Paulus se briewe te stimuleer.

Non-real questions in 1 Corinthians 5-6. In this article, questions previously distinguished in traditional grammars and commentaries as mainly real or rhetorical, are classified in terms of a model developed from speech act theory. Instead of classifying all non-real questions as rhetorical questions (as commentators tend to do), the model makes provision for six main and various sub-categories of non-real questions. The model is briefly summarised, followed by a systematic investigation of all the questions in 1 Corinthians 5-6. The conclusion is that the proposed model is useful for distinguishing various types of non-real questions within a scientific framework and for determining their communicative functions, thereby contributing to the translation and exegesis of the passages involved. The model could stimulate research on the role of non-real questions in all Paul's letters.

\section{Inleiding}

Die vraagvorm as konstruksie word tot ' $n$ meerdere of mindere mate in alle Griekse grammatikas en kommentare op die Nuwe Testament (NT) bespreek. Waar Griekse grammatici hoofsaaklik formele onderskeidings maak, beskou kommentators alle nie-egte vrae as retoriese vrae, sonder om hulle verder te onderskei of aan te toon hoe hulle die kommunikasie van die boodskap versterk.

In hierdie artikel word die probleem onder die loep geneem aan die hand van 'n model gebaseer op die taalhandelingsteorie en op 1 Korintiërs 5-6 toegepas. Die stof word soos volg verdeel:

- 'n bespreking van vrae in tradisionele grammatikas en kommentare

- die taalhandelingsteorie as raamwerk vir die onderskeiding van verskillende soorte vrae

- nie-egte vrae en hulle funksies in 1 Korintiërs 5-6

- slotsom.

\section{Vrae in tradisionele grammatikas en kommentare}

'n Tipiese voorbeeld van die wyse waarop Griekse grammatikas vrae bespreek, is te vind in die werke van Moulton en Turner. In sy eerste volume het Moulton (1908:170-194) dit veral oor die onderskeiding tussen $\mu \Upsilon \mu \Upsilon \tau \imath$ en ou vrae, terwyl Turner (1963:48-50, 282-283, 330-337) onderskei tussen direkte en indirekte vrae. Hy gaan ook verder in op formele sake soos die verwarring tussen relatiewe en vraende voornaamwoorde, die beraadslagende vraag, partikels wat vraagvorme inlei en die gebruik van direkte vraende voornaamwoorde.

Soortgelyke sake is aan die orde in die meeste ander grammatikas soos dié van Robertson (1919:1043-1046, 1175-1177); Chamberlain (1957:204-210); Goetchius (1965:228-233); Argyle (1965:20, 105-106); en Nunn (1973:82, 127). Burton (1955:76-78) onderskei tussen 'questions of fact and questions of deliberation', asook tussen 'interrogative or real questions and rhetorical questions', terwyl die grammatika van Blass, Debrunner en Funk (1967:272) vier soorte vrae onderskei: direkte vrae, indirekte vrae, retoriese vrae en dubbele vrae. Veral laasgenoemde twee grammatikas is 
vir ons doel belangrik en sommige van hulle onderskeidings word hieronder verder gevoer.

In die eerste Afrikaanse grammatika oor die Griekse NT, Grieks met Begrip, word vraagsinne behandel onder die hoofde 'Informatiewe vrae', 'Nie-informatiewe of retoriese vrae', 'Vraagsinne ingelei deur vraende voornaamwoorde', en 'Indirekte vrae' (Conradie \& Barkhuizen 1995:415-420). Die onderskeiding tussen informatiewe en nie-informatiewe of retoriese vrae bevat ' $n$ interessante bespreking van vrae waarop die antwoord ja en dié waarop die antwoord nee verwag word, met bruikbare voorstelle vir die vertaling daarvan in Afrikaans.

Standaardkommentare oor 1 Korintiërs soos dié van Conzelmann (1975), Fee (1988) en Thiselton (2000) beskou alle vrae as retoriese vrae. Conzelmann bespreek hulle as deel van Paulus se diatribe/dialogiese styl. Fee gee veral aandag aan die funksies van dié soort vrae, naamlik om 'n argument mee te begin of af te sluit, terwyl Thiselton die vertaling van $\mu$ Yov vrae en die gevoelswaarde van retoriese vrae uitlig. Bratcher (1982) fokus op vertaling en is ten gunste van die herskryf van die meeste retoriese vrae in 1 Korintiërs 5-6 as stellings - iets wat oorweging verdien en ook hieronder bespreek word.

Om saam te vat: tradisionele grammatikas onderskei hoofsaaklik tussen informatiewe en nie-formatiewe vrae (met enkele opmerkings oor die funksies van laasgenoemde), terwyl kommentare slegs die retoriese vraag ken en sporadiese opmerkings daaroor maak.

Hiermee is die verskillende vraagvorme met hulle funksies egter nie uitgeput of sistematies aan die hand van 'n teoretiese raamwerk ondersoek nie. In wat volg wil ek dit probeer doen en ook illustreer aan die hand van al die vrae in 1 Korintiërs 5-6. In die proses word na die interpretasie en vertaling van vrae deur kommentators en vertalers verwys en word aanbevelings gemaak waar nodig. Daar word ook 'n saaklike evaluasie van die voorstel van Verster gegee, aangevul met relevante literatuur.

\section{Die taalhandelingsteorie as raamwerk vir die onderskeiding van verskillende soorte vrae}

In sy studie van nie-egte vrae in die Romeinebrief het Verster (1999:1) ook gevind dat kommentators alle soorte vrae in die brief as retoriese vrae beskou. Dit het daartoe gelei dat hy begin soek het na 'n teorie wat fyner onderskeiding moontlik maak. Die doel van sy studie was om 'n model uit relevante literatuur oor die taalhandelingsteorie af te lei, nieegte vrae aan die hand daarvan in te deel, die model op die Romeinebrief te toets, en dit dan, indien nodig, aan te pas (1999:1-2).

Sy eerste hoofstuk handel oor die grondslae van die taalhandelingsteorie (1999:3-28). Hy volg dit op met 'n deeglike bespreking van nie-egte vrae as taalhandelinge (1999:29-54), waarna hy eers egte en nie-egte vrae van mekaar onderskei en dan 'n aantal kategorieë van nie-egte vrae identifiseer. By egte vrae maak die mededeler $(M)$ gebruik van die vraagvorm om inligting te bekom, terwyl nie-egte vrae nóg inligting, nóg 'n antwoord van die ontvanger $(O)$ verlang. Elke kategorie nie-egte vrae is voorsien van 'n aantal kriteria op grond waarvan dit van die ander onderskei kan word (1999:55).

Die kategorieë nie-egte vrae is die volgende (Verster 1999:56-68):

- Vrae wat aksie verlang, waaronder direktiewe, wat die vraagvorm gebruik vir opdragte, versoeke en uitnodigings.

- Vrae wat stellings maak, waar die vraagvorm as 'n gewone stelling herskryf kan word, gewoonlik nie met absolute sekerheid nie; retoriese vrae, wat stellings met besondere intensiteit maak; en meta-kommunikatiewe retoriese interrogatiewe, waar $M$ gevolgtrekkings maak oor 'n aksie wat deur $O$ geneem is.

- Leë vraagstellings, waar $M$ reageer op 'n taalhandeling van $O$, en 'n negatiewe stelling maak waardeur die gesprek onderbreek word.

- Vrae wat emosie oordra, waaronder jubelvrae en lamentasies. Ook hier word geen inligting verlang nie, maar word die vraagvorm gebruik om 'n bepaalde emosie te versterk of uit te druk. Dit is vraagvorme waar 'n eksterne $O$ afwesig kan wees.

- Monologiese selfgerigte vrae, wat van ander nie-egte vrae onderskei word daarin dat hulle besinnend van aard is, en gewoonlik aan $M$ self ( $e$ of ons) gerig is. Hulle kan primêr emosioneel of primêr rasioneel wees.

- Rasioneel-argumentatiewe vrae, waaronder vraagappélle, wat nie 'n reaksie van $O$ verwag nie, maar sy of haar aandag wil kry vir 'n nuwe tema of 'n stelling wat $M$ self wil maak; en ironiese retoriese interrogatiewe, waar die betekenis van die nie-egte vraag nie op die oppervlak lê nie, maar in die teenoorgestelde van wat deur die vraag geïmpliseer word. Die vraag moet in die konteks van 'n ironiese toespeling verstaan word. Vraagappélle en ironiese vrae dien albei om 'n argument te ontwikkel. Daarom is hulle onder hierdie hoofkategorie ingedeel.

Om bogenoemde soorte vrae te onderskei, is die onmiddellike konteks waarin hulle voorkom, maar veral die konteks van die brief as geheel, van deurslaggewende belang. In die taalhandelingsteorie word na laasgenoemde verwys as Gedeelde Kontekstuele Kennis (GKK), wat betrekking het op kennis van sosiale sisteme, tradisionele gewoontes, spesifieke gespreksituasies en veral die verhouding tussen spreker en hoorder (Verster 1999:70-71). Die vier aspekte word gewoonlik toegelig deur'n bespreking van die skrywer, lesers, inhoud en doel van 'n brief, wat alles nodig is om die soorte vrae in die brief reg te onderskei.

Met bogenoemde voorstel het Verster dit moontlik gemaak om nie-egte vrae in die NT te bestudeer in die lig van onderskeidings eie aan 'n erkende taalteorie. Die hoof- en subkategorieë wat hy onderskei, kan egter vereenvoudig word. Naas die ses hoofkategorieë hierbo gelys, onderskei hy ook 'n sewende een, naamlik temaversterkers. Die kategorie word nie in hierdie artikel verreken nie, omdat 
temaversterkers (soos vraagappélle) aandag vra vir 'n nuwe tema of stelling wat $M$ wil maak. Hulle kan dus as vraagappélle geklassifiseer word. Verder kan die term retories geskrap word in die beskrywing van die twee subkategorieë meta-kommunikatiewe retoriese interrogatiewe en ironiese retoriese interrogatiewe, omdat daar reeds subkategorie retoriese vrae is. Daar word ook voorgestel dat die hoofkategorie van vrae wat emosie oordra, verdeel word in positiewe emosies (soos dankbaarheid en blydskap) en negatiewe emosies (soos afsku, teleurstelling en verontwaardiging), omdat die terme jubelvrae en lamentasies nie oorkoepelend genoeg is nie. Origens is dit 'n bruikbare model, wat met vrug in die studie van vrae in Paulus se briewe gebruik kan word.

Vervolgens word bogenoemde model gebruik om die verskillende soorte vrae in 1 Korintiërs 5-6 te identifiseer en hulle funksies binne konteks te bepaal.

\section{Nie-egte vrae en hulle funksies in 1 Korintiërs 5-6 Inleiding}

Inligting oor die skrywer, lesers, doel en inhoud van die brief is in elke goeie kommentaar te vind en kan soos volg weergegee word: 'Die gemeente van God wat in Korinte is' (1 Kor 1:2) was 'n jong gemeente, wat in 'n korrupte wêreldstad met verskeie vraagstukke te kampe gehad het. Die gelowiges uit die heidendom moes duidelikheid kry omtrent die Christen se houding teenoor 'n verskeidenheid gebruike en beskouinge in hulle omgewing. Hiervoor het hulle leiding gesoek by Paulus, maar in die proses ook partyskappe gevorm.

Die eerste doel van die brief was juis om die partyskappe en onderlinge twiste in die gemeente te hanteer. Hierdie twiste het implikasies gehad vir Paulus se apostoliese gesag en word hoofsaaklik in hoofstukke 1 tot 4 van 1 Korintiërs behandel. Die belangrikste verskilpunt was oor die betekenis

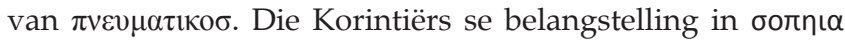

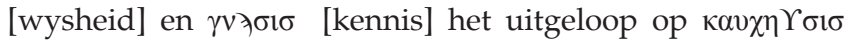
[selfverheffing of roem], wat radikaal ingedruis het teen Paulus se boodskap.

Volgens Fee (1988:194-195) is die kwessie van Paulus se apostoliese gesag ook die tema van hoofstukke 5 en 6 van 1 Korintiërs. In die twee hoofstukke bespreek hy 'n aantal nuwe, hoofsaaklik morele probleme, wat die mense van Chloë mondelings onder sy aandag gebring het. Die probleme handel oor onsedelikheid en die wyse waarop die gemeente dit hanteer het (5:1-13); hofsake tussen gelowiges wat na wêreldse geregshowe geneem is (6:1-11); en die verontreiniging van die liggaam as 'tempel van die Heilige Gees' (6:12-20). In die twee hoofstukke bespreek Paulus hierdie kwessies aan die hand van die evangelie en probeer hy op dié wyse sy gesag as apostel verseker.

'n Tweede doel van die brief was om te reageer op sekere praktiese aangeleenthede wat in die brief waarna in 1 Korintiërs 7:1 verwys word, geopper is. Die belangrikste hiervan was die huwelik en seksualiteit (1 Kor 5-7); die eet van vleis wat aan die afgode geoffer is (1 Kor 8:1-11:1); gemeentelike orde en die gawes van die Gees (1 Kor 11:2-14:40), en die opstanding (1 Kor 15:1-58). 'n Addisionele doel van die brief was om leiding oor hierdie, hoofsaaklik praktiese, kwessies te gee. Hoofstukke 5 en 6 is, soos hoofstukke 1 tot 4 van 1 Korintiërs, sterk argumentatief. In die proses maak Paulus van verskillende soorte vrae gebruik, wat vervolgens bespreek sal word.

\section{Nie-egte vrae in hoofstukke 5-6}

Nie een voorbeeld van ' $n$ egte vraag word in die twee hoofstukke gevind nie. Van die ses hoofkategorieë nie-egte vrae wat hierbo gelys is, kan egter net vier geïdentifiseer word. Die twee wat ontbreek, is vrae wat aksie verlang (direktiewe) en leë vraagstellings, wat die gesprek onderbreek.

Die vier kategorieë, met hulle onderafdelings, is die volgende:

\section{Vrae wat stellings maak}

Retoriese vrae: Retoriese vrae gebruik die vraagvorm. Die vraag is egter nie bedoel om inligting te bekom nie, maar om stellings te maak. Dit word afgegrens van meta-kommunikatiewe interrogatiewe, omdat dit nie gevolgtrekkings maak nie, en van gewone vraagstellings, omdat dit stellings met groot stelligheid of besondere intensiteit maak. Hoewel dit moeilik is om dié soort vraagvorm te onderskei en daar altyd verskil van mening sal wees, lyk dit of die volgende kriteria 'n aanduiding van besondere intensiteit kan wees: die gebruik van aanspreekvorms; kort sinne; kragtige uitdrukkings en sterk werkwoorde; partikels wat die stelligheid bevestig; en herhaling van strukture en begrippe.

Vyf voorbeelde van retoriese vrae word in hoofstuk 6 gevind. Die vertalings is eie (betreklik letterlike) weergawes van die oorspronklike Grieks in 1 Korintiërs 6:7: ‘Waarom ly julle nie liewer onreg nie? Waarom laat julle julle nie liewer te kort doen nie?'

Die twee vrae is bondig geformuleer en het presies dieselfde sintaktiese struktuur in die oorspronklike taal. Hulle begin met dieselfde woorde en eindig met dieselfde lettergrepe. Die twee werkwoorde is ook albei in die medium. Albei vraagvorme kan dus as stellings met intensiteit herskryf word: Ly dan liewer onreg! Laat doen julleself liewer te kort!

Met die twee vraagvorme bou Paulus voort op sy aanklag teen die Korintiërs, wat met hulle hofsake na wêreldse regbanke gaan. In 1 Korintiërs 6:1-6 het hy geargumenteer dat hulle moet probeer om ' $n$ geskil in eie kring te besleg deur ' $n$ verstandige gelowige as arbiter in te roep. Hier in 6:7 redeneer hy nou dat hofsake as sodanig reeds verkeerd is. Hulle moet liewer onreg ly en hulleself te kort doen as om 'n medegelowige na 'n wêreldse geregshof te sleep. Dan pleeg hulle geen onreg nie en belewe hulle die wins van 'n Christelike etiek. Deur onverdiend onreg te verduur, verstaan hulle en neem hulle deel aan die $\varepsilon \alpha v \gamma \varepsilon \lambda ı \alpha \chi \rho \nu \chi 1 \sigma$ (Fee 1988:241).

Die funksie van die twee retoriese vrae is om laasgenoemde kernwaarheid met groot stelligheid tuis te bring. Hoewel 
hulle as stellings vertaal kan word, behoort hulle as vrae behou te word ten einde die impak van die kommunikasie te verhoog: 'Weet julle nie dat julle liggaam deel is van Christus nie? Sal ek nou 'n deel van Christus neem en dit deel van 'n ontugtige vrou maak? Beslis nie!' (1 Kor 6:15); 'Of weet julle nie dat iemand wat met 'n ontugtige vrou omgang het, liggaamlik een met haar is nie? God sê immers: "Die twee sal een word"' (1 Kor 6:16); 'Maar wie hom met die Here verenig, is geestelik een met Hom' (1 Kor 6:17).

Die drie verse vorm 'n integrale deel van die argument in 1 Korintiërs 6:12-20. Hulle is al drie aangehaal omdat hulle inhoudelik ten nouste saamhang en deur 'n chiastiese struktuur aan mekaar verbind word:

- deel van die liggaam van Christus (6:15a)

- deel van 'n ontugtige vrou (6:15b)

- liggaamlik een met 'n ontugtige vrou (6:16)

- geestelik een met God (6:17).

Die drie vrae in 1 Korintiërs 6:15-16 moet binne dié konteks verstaan word. Anders as by gewone vraagstellings, word al drie vraagvorme gekenmerk deur besondere intensiteit. (Om dié rede, asook vanweë die chiastiese struktuur wat hulle bind, word die twee Weet julle nie?-vrae hier behandel en nie onder die kategorie vraagappélle hieronder nie). Die intensiteit van die vraagvorme in 6:15-16 blyk eerstens uit die herhaling daarvan en die wyse waarop hulle op mekaar bou (Barrett 1979:148; Groenewald 1967:74-75). In 6:13-14 argumenteer Paulus dat ontug nie 'n onbenullige saak (soos die eet van voedsel) is nie, maar dat dit direk indruis teen dit waarvoor die menslike liggaam wat aan Christus behoort en wat God uit die dood sal opwek, bedoel is. Hierop bou hy in 6:15-17 op 'n kragtige wyse voort met die drie vraagvorme, soos Lenski (1963) dit stel:

The latter (15-16) rests on the former (13-14), but by combining it with the former Paul brings the enormity of this sin fully to the consciousness of the Corinthians. The presentation continues in its simple and lucid manner by using the facts so that their force overwhelms. (p. 261 [outeur se eie vertaling])

Die intensiteit van die vraagvorme blyk tweedens uit die herhaling van sleutelterme, soos uitgewys in die chiasme hierbo: die liggaam as deel van Christus (1 Kor 6:15a-b); 'deel van 'n ontugtige vrou'; en 'iemand wat met 'n ontugtige vrou omgang het' (6:15b-16).

'n Derde rede waarom die drie vraagvorme retoriese vrae is, is die sterk ontkenning aan die einde van 1 Korintiërs 6:15: 'Beslis nie!' Dit bevestig die intensiteit waarmee Paulus hier argumenteer.

Die bondige formulering van die vrae is ook ' $\mathrm{n}$ kriterium van intensiteit. Al drie vrae kan as sterk stellings herskryf word, en wel met die gebruik van invoegings soos mos (nie), of tog (nie) (Conradie \& Barkhuizen 1995:416). Hoewel dit moontlik is, behoort hulle as retoriese vrae vertaal te word om hulle oorredingskrag te versterk.

\section{Vrae wat emosie oordra}

Anders as by vraagstellings waar die vraagvorm in stellingvorm oorgeskryf kan word, gaan dit in hierdie kategorie nie om 'n stelling wat gemaak word nie, maar om 'n emosie wat oorgedra word. Hierdie soort vrae is nie-egte vrae, omdat hulle nie inligting verlang nie, maar emosie wil oordra. Kriteria wat gebruik kan word om die soort vraag te identifiseer, sluit in ongewone sintaksis, $\alpha \sigma v v \delta \varepsilon \tau$ ov en dan natuurlik die konteks waarbinne dit voorkom. Met hierdie vraagvorm verwag $M$ emosionele instemming van $O$; sy doel is om $O$ by die emosie te betrek (Verster 1999:100-106).

Die kategorie word verdeel in vrae wat positiewe emosies en vrae wat negatiewe emosies oordra. Slegs een voorbeeld van laasgenoemde word in 1 Korintiërs 5-6 gevind, en wel in 6:1: 'Durf iemand van julle wat 'n saak teen 'n ander het, sy reg by heidense regters gaan soek, en nie by gelowiges nie?'

Die vraag sluit aan by Paulus se vorige argument aan die einde van hoofstuk 5, waar hy daarop aandring dat die kerk nie diegene wat buite is, moet oordeel nie, maar wel diegene wat binne is (1 Kor 5:12-13). In 6:1 wend hy hom nou tot 'n spesifieke voorbeeld in die gemeente, waar iemand van binne' $n$ saak teen 'n medegelowige gehad en daarmee na die wêreldse regbank (daar buite) gegaan het. Die geval het hom hewig ontstel. Sy ontsteltenis vloei voort uit die feit dat die Korintiërs, wat hulleself so hoog geag en op hulle wêreldse wysheid geroem het, so min verstaan het van wie hulle in Christus is dat hulle so-iets kon doen. Verder was dit praktyk in die Joodse gemeenskap om geskille intern te besleg, en was daar Griekse en Romeinse godsdienstige groeperinge wat dieselfde gedoen het. Hoe kón die Korintiërs dan, wat baie sterker gronde gehad het om hulle geskille onder mekaar te besleg, dit nie ook doen nie? (Barrett 1979:135-136).

Skrifverklaarders stem saam dat 1 Korintiërs 6:1 gelaai is met emosie. Hulle verskil egter oor die aard daarvan. Volgens Thiselton (2000:423) belewe Paulus hier 'n gevoel van verontwaardiging en teleurstelling. Groenewald (1967:72) reken ook dat die vraag verontwaardiging uitdruk, terwyl Fee (1988:231) van mening is dat Paulus gewoon met afsku vervul is oor wat hy gehoor het. Die hele paragraaf $(6: 1-11)$ is, volgens hom, só vol emosie dat daar nouliks enige argument gevoer word.

Die vraag in 1 Korintiërs 6:1 druk sterk negatiewe gevoelens uit. Dit kan na my mening ook gekwalifiseer word as verontwaardiging en is duidelik te onderskei van die soorte vraagvorme wat in 6:2-4 volg (sien hieronder by die vraagapélle). In dié vraagapél begin Paulus sonder enige partikel wat sy vraagvorm aan die vorige paragraaf verbind ( $\alpha \sigma v v \delta \varepsilon \tau o v)$. Sy sintaksis is ook ongewoon. Hy begin die sin met die werkwoord $\tau$ o $\lambda \mu \alpha$, wat dit volgens Fee (1988:231) moeilik maak om die sin in goeie Engels te vertaal, terwyl die vertaling 'iemand van julle wat 'n saak teen 'n ander het' ook problematies is. Die voorsetsel teen (in Grieks $\pi \rho \circ \sigma)$ dui op wederkerigheid, wat beteken dat een van hulle 'n eis teen die ander ingestel het, waarop laasgenoemde reageer het met 'n teen-eis. Word die sinsdeel egter wederkerig vertaal (julle ' $n$ saak teen mekaar het), skep die eerste deel van die sin (een van julle) in die oorspronklike weer probleme (Lenski 1963:234). Hierdie ongewone sintaksis wys op die emosie waarmee die vraag in 6:1 geformuleer is. 
Die vraagvorm in 1 Korintiërs 6:1 word onderskei van die vraagvorme wat in 6:2-11 volg, omdat laasgenoemde die redes vir Paulus se ontsteltenis in 6:1 verskaf.

\section{Monologiese selfgerigte vrae}

Hierdie kategorie vrae kan onderskei word van ander hoofen subgroepe vrae daarin dat hulle monologies en refleksief is. Hulle is ook nie-egte vrae, omdat geen inligting verlang word nie. Die vrae is besinnend van aard en word gewoonlik gemerk deur die eerste persoon enkelvoud of meervoud. Soos altyd spreek die konteks ook mee by die identifisering van hierdie soort nie-egte vrae (Verster 1999:107-110).

Voorbeelde van die soort vrae, dien: 'Want waarom sou ek ook die wat buite is oordeel? Oordeel julle nie die wat binne is nie?' (1 Kor 5:12) en 'Maar die wat buite is, oordeel God. Verwyder tog die slegte mens onder julle uit' (1 Kor 5:13).

Die twee vrae neem ons terug na die vorige hoofstuk oor die onsedelike persoon in die gemeente wat nie gedissiplineer word nie. Met vier kort sinne sluit Paulus sy argument oor die saak af. Die ordening van die vrae en stellings, asook die vertaling van die vrae as vraagstellings, hou Skrifverklaarders steeds besig. Fee (1988:220-227) behou bogenoemde orde van die Griekse teks en wys op die AB/AB konstruksie daarvan: eers twee vrae oor diegene wat die kerk nié oordeel nie en dié wat dit wel doen (1 Korintiërs 5:12), en daarna twee response op die vrae in vers 13. Volgens Conzelmann (1975:102) is die uiteensetting hier gedronge en moeilik om te volg. Dit wil voorkom asof 5:12b ingevoeg is tussen 5:12a en 5:13. Om egter die orde te verander, sou verkeerde aksente plaas op wat Paulus bedoel. Paulus sluit homself nie uit by die funksie om te oordeel nie, maar verduidelik dat hy en diegene wat tot die gemeente behoort, nie bevoeg is om hulle daar buite te oordeel nie.

In teenstelling met Fee (1988), Conzelman (1975), Groenewald (1967:71) en Barrett (1979:120, 132-133), steun Bratcher (1982:46-47) die Todays English Version (TEV), wat die twee sinne oor diegene daar buite saamgroepeer, gevolg deur die twee wat handel oor die persone binne die gemeente. Die herskikking van sinne word ook gevind in die 1983-vertaling van die Afrikaanse Bybel, maar dit verskil van die TEV ten opsigte van watter sinne as vrae, en watter as stellings vertaal is.

Bogenoemde verwysings illustreer die probleem. Watter interpretasie is die beste? Hoewel daar altyd meningsverskil sal wees, verkies ek om die orde van die sinne in die Grieks te behou en die eerste twee as vrae, en die laaste twee as stellings te vertaal. My motivering is tweërlei:

- Die twee vraagvorme in 1 Korintiërs 5:12 hoort bymekaar omdat die tweede een gebruik word om die eerste een toe te lig, soos Conzelmann tereg aangetoon het. Wanneer hulle van mekaar geskei word op grond van die buite/ binne kontras, gaan die toeligting verlore.

- Die vraagvorme moet as vrae vertaal en nie as stellings herskryf word nie, omdat Paulus besinnend met homself en die ontvangers besig is en op dié manier sy argument opbou. In dié opsig verskil dit van vraagstellings en retoriese vrae wat stellings met groot intensiteit maak. Binne die raamwerk van dié artikel is hulle selfondersoekende interrogatiewe wat as vrae vertaal behoort te word.

Daar word dus voorgestel dat die orde van die vier sinne in 1 Korintiërs 5:12-13 behou word, en dat die eerste twee vraagvorme as (monologiese selfgerigte) vrae vertaal word om die impak van die kommunikasie te verhoog.

\section{Rasioneel-argumentatiewe vrae}

Hierdie kategorie bevat net twee soorte vrae, naamlik die vraagappélle en ironiese interrogatiewe. Voorbeelde van albei word in 1 Korintiërs 5-6 gevind.

Vraagappélle: Hierdie soort nie-egte vrae word gebruik met die betekeniswaarde van appélle, met ander woorde die vrae word gevra om die aandag van $O$ te kry. Geen verbale reaksie word van $O$ verwag nie, omdat $M$ self die antwoord verskaf, hetsy met ' $n$ reeks stellings of in die vorm van 'n volgende vraag wat op die vraagappél bou. Die doel van 'n vraagappél is gewoonlik om 'n nuwe tema in te lei; in uitsonderlike gevalle ook om 'n bestaande argument verder te voer. Omdat $M$ self die antwoord gee en nie ' $n$ antwoord van $O$ verwag nie, is dit 'n tipiese voorbeeld van 'n nie-egte vraag. Dit is 'n effektiewe manier om $O$ by die argument te betrek. En soos gewoonlik help die konteks ons om 'n vraagappél te identifiseer (Verster 1999:110-117).

Die kenmerk van die vraagappélle in hoofstukke 1 Korintiërs 5 en 6 is dikwels die bekende vraagvorm: 'Weet julle nie dat ...?', wat tereg deur Conzelmann (1975:94-113), Fee (1988:198-267), Barrett (1979:119-152) en Lenski (1963:216-271) beskou word as 'n navolging van die diatribestyl van redevoering. Die styl was gewild by (hoofsaaklik moralistiese) filosowe van daardie tyd. Hulle het die vraagvorm gebruik om hulle gehoor by 'n denkbeeldige debat te betrek. Paulus gebruik die vraagvorm 10 keer in die brief, sewe keer in ons twee hoofstukke. Die doel daarvan is nie soseer om die Korintiërs te herinner aan iets wat hulle reeds meegedeel is nie, maar om te wys op iets wat hulle uit die aard van die saak behoort te weet of te geweet het. Uit hulle gedrag is dit egter duidelik dat hulle nie weet of geweet het nie, of nie die implikasies van hulle optrede deurdink het nie (Fee 1988:146).

Die volgende vraagappélle word in hoofstukke 1 Korintiërs 5 en 6 gebruik: 'En dan is julle opgeblase? Moes julle nie liewer getreur het nie, sodat hy wat hierdie daad verrig het, uit julle midde verwyder kan word nie?' (1 Kor 5:2).

Die Grieks het die hele sin as een vraag geformuleer. Fee (1988:198) en Thiselton (2000:384) het die eerste deel geskei van die res van die sin en dit as 'n uitroep vertaal, gevolg deur 'n vraag. Conzelmann (1975:94) het dit egter as een vraag vertaal, met die opmerking dat die nıva nie doel nie, maar gevolg aandui. Barrett (1979:122), weer, het die sin as twee vrae vertaal: 'Are you in these circumstances puffed up? Do you not rather go into mourning that he who had committed this deed might be taken away from you?' 
Dieselfde verskeidenheid word in Bybelvertalings gevind. In die 1933/1953-vertaling van die Afrikaanse Bybel is die hele sin as 'n stelling vertaal, terwyl die 1983-vertaling die teks in drie sinne verdeel het met ' $n$ vraag in die middel: 'Moes julle nie liewer daaroor getreur het nie?' Die TEV en die New International Version (NIV) het die teks in twee sinne verdeel, maar verskil oor watter een as ' $n$ vraag en watter een as ' $n$ stelling vertaal moet word. Dit illustreer nogeens hoe moeilik dit is om vraagstellings van vraagappélle te onderskei.

Waarom is 1 Korintiërs 5:2 dan 'n vraagappél? Daar is na my mening twee redes, wat albei uit die konteks afgelei kan word:

- Dit lei 'n nuwe tema in, naamlik dié van kerklike dissipline of tug. In 5:1 word 'n geval van onsedelikheid beskryf: 'n man wat saam met sy (stief)ma leef, iets wat selfs nie onder die heidene voorgekom het nie. Om dit te hanteer, stel Paulus die tema van kerklike dissipline aan die orde, en wel by wyse van 'n vraagappél wat sy lesers se aandag vestig op die nuwe tema en hulle by die argument betrek.

- Die vraagappél word volledig in 5:3-5 deur Paulus self beantwoord: Wat hóm betref, het hy reeds besluit om so iemand aan die Satan oor te lewer. In terme van die voorgestelde model is dit dus 'n tipiese vraagappél. In die oorspronklike taal word die vraagappél en sy antwoord ten nouste aan mekaar verbind deur julle (in 5:2) en wat my betref (in 5:3) albei aan die begin van die sinne, dit wil sê in beklemtoonde posisies, te plaas.

Wat die vertaling betref, behoort die sin in vraagvorm (as vraagappél) behou te word. Om dit makliker leesbaar te maak en die impak daarvan te verhoog, kan dit in twee verdeel word, soos hierbo aangedui.

In die res van die hoofstuk (1 Kor 5:6-13) brei Paulus verder uit op die tema van kerklike dissipline en gebruik hy onder meer ' $n$ tweede vraagappél in 1 Korintiërs 5:6b: 'Weet julle nie dat 'n bietjie suurdeeg die hele deeg deurtrek nie?'

Die beeld wat die apostel hier gebruik, verwys na die voorskrifte vir die paasfees in Eksodus 12:15 e.v. en Eksodus 13:7 (Barrett 1979:127-128; Groenewald 1967:69-70). Paulus sluit nou hierby aan wanneer hy sy appél in 5:6b rig. Die Korintiërs moet besef dat hulle verdraagsaamheid teenoor die sedelose man in hulle midde, die hele gemeente in gevaar stel. Die gemeente word voorgestel as voorbereide deeg en die Korintiërs weet mos dat een stukkie suurdeeg die hele deeg deursuur.

Met hierdie bekende beeld vra Paulus die aandag van sy lesers vir wat hy in 1 Korintiërs 5:7-8 wil uiteensit. Hy volg die vraagappél op met 'n bevel om die ou suurdeeg te verwyder, sodat die gemeente kan feesvier 'met die ongesuurde brood van reinheid en waarheid' (5:8). Die vraagvorm in 5:6b is 'n vraagappél, omdat dit 'n nuwe punt in Paulus se argument oor kerklike dissipline inlei, en wel met inligting wat hy self verskaf. Deur die vraagappél word sy lesers by die argument betrek: 'Weet julle nie dat die heiliges die wêreld sal oordeel nie? En as julle oor die wêreld sal oordeel, is julle dan onbevoeg vir die geringste regsake?' (1 Kor 6:2).
Die twee vraagvorme volg op die emosionele 1 Korintiërs 6:1 wat hierbo bespreek is en word tot die hele gemeente gerig, omdat hulle toegelaat het dat 'n gelowige met sy regsaak teen 'n ander gelowige na die wêreldse geregshof gaan. Met die twee vraagvorme in 6:2, lei Paulus 'n nuwe tema in wat deurloop tot by vers 6: Die gelowiges is mense van die eindtyd wat betrokke gaan wees by die voltrekking van God se oordeel oor die wêreld. Hierdie veronderstelling is 'n bekende motief uit die Joodse apokaliptiese eskatologie (Qumran 1) en Paulus gebruik dit hier om die onsinnigheid van regsake in die huidige bedeling te belig. As die Korintiërs dan die wêreld gaan oordeel, hoekom tree hulle op asof hulle nie eens die bevoegdheid het om oor geringe persoonlike geskille uitspraak te lewer nie? (Fee 1988:233-234). Dit gee die rede vir Paulus se hewige ontsteltenis in 6:1.

Volgens Barrett (1979:136) en Lenski (1963:236) is 1 Korintiërs 6:2 'n voorbeeld van 'n argumentum a majori ad minus: as toekomstige beoordelaars van die wêreld (wat 'n groot saak is), is die gelowiges meer as bevoeg om oor persoonlike geskille (wat 'n geringe saak is) te oordeel. Deur dié bekende oorredingstegniek word die twee vraagappélle ten nouste aan mekaar verbind en dien hulle albei om die tema van die kerk as 'n eskatologiese gemeenskap in te lei: 'Weet julle nie dat ons oor die engele sal oordeel nie, hoeveel te meer oor die alledaagse dinge?' (1 Kor 6:3).

Met hierdie vraagappél word die vraagappélle in 1 Korintiërs 6:2-3 tot 'n einde gebring. Die gedagtegang is parallel aan dié van die vorige vers en brei daarop uit met nog 'n argumentum a majori ad minus: As hulle selfs die engele gaan oordeel, behoort dit vir hulle'n geringe saak te wees om oor alledaagse dinge reg te spreek (Conzelmann 1975:105; Thiselton 2000:430).

Paulus gebruik dus in 1 Korintiërs 6:2-3 'n reeks vraagappélle om sy argument te bou. Die een vraag volg op die ander, sonder dat hy self ' $n$ antwoord verskaf of een van sy lesers verwag. Die rede hiervoor is waarskynlik sy ontsteltenis oor die absurditeit van dit wat die Korintiërs besig was om te doen: as gelowiges gaan hulle die wêreld oordeel, dieselfde wêreld tot wie hulle hulle nou wend om hulle persoonlike regsake te besleg! Dit is vanuit hierdie eskatologiese perspektief dat Paulus se hele argument, asook die funksie van die vraagappélle in die gedeelte, verstaan moet word: 'Of weet julle nie dat die onregverdiges die koninkryk van God nie sal beërwe nie?’ (1 Kor 6:9).

Die vers is steeds deel van Paulus se ernstige besorgdheid in 1 Korintiërs 6:1-11, maar word onderskei van 6:2-3 deurdat dit gevolg word deur ' $n$ duidelike en volledige antwoord in 6:10-11. In terme van Verster se klassifikasie is dit dus ' $n$ tipiese vraagappél, wat die argument in 6:1-11 versterk: 'Of weet julle nie dat julle liggaam 'n tempel is van die Heilige Gees wat in julle is, wat julle van God het, en dat julle nie aan jullself behoort nie?' (1 Kor 6:19).

In hierdie konteks (1 Kor 6:13-20) gaan dit oor seksuele losbandigheid. Vir die hoogmoedige Korintiërs het die teenwoordigheid van die Heilige Gees beteken dat hulle 
liggame nie belangrik was nie. As geestelike mense kon hulle daarmee doen wat hulle wou. Paulus redeneer nou presies die teenoorgestelde: die Heilige Gees wóón in hulle liggame, en daarom behoort hulle nie aan hulleself nie, maar aan God. Dit is 'n tipiese vraagappél, en dit word gevolg deur 'n motivering en 'n oproep wat Paulus self verskaf (6:20).

Ironiese interrogatiewe: Hierdie soort vraagvorm word gebruik om 'n nie-egte vraag uit te druk waarvan die betekenis nie op die oppervlak van die vraag lê nie, maar in die teenoorgestelde van wat deur die vraag geïmpliseer word. Die vraag moet uit die onmiddellike of breë konteks verstaan word as 'n ironiese toespeling (Verster 1999:67-68). Hierdie beskrywing van ironie stem ooreen met die studie van Karl Plank. In sy bekende werk Paul and the irony of affliction (1987) het hy verskeie definisies van ironie bestudeer en drie kenmerke gevind wat by almal voorkom:

First, irony occurs through an indirect use of language and expresses a covert meaning. The meaning of ironic language lacks self-evidence and must be reconstructed by the reader. Second, the indirect use of language reflects a contrast between appearance and reality. In the ironic text things are not simply as they appear to be. Third, irony works through the introduction or implication of a second perspective from which the text's obvious meaning can be reinterpreted. (Plank 1987:37)

Om ironie in ' $n$ literêre teks te verstaan speel die konteks en 'n sekere kennis van die outeur se oortuigings 'n deurslaggewende rol, soos Plank in sy studie aangetoon het. Hierdie kennis help die leser om die werklikheid waarmee die oënskynlike vraag kontrasteer, te verstaan en so die ironie te begryp. Die betekenis van hierdie indirekte taalgebruik moet deur die leser self gerekonstrueer word.

Drie voorbeelde van ironiese interrogatiewe word in hoofstuk 6 uitgelig, waaronder: 'As julle dan alledaagse regsake het, laat julle die persone daaroor sit wat in die gemeente die minste geag word?' (1 Kor 6:4).

Die vraag begin met dieselfde Griekse term waarmee die vraag in 1 Korintiërs 6:3 afsluit, naamlik $\beta$ io $1 \kappa \alpha$, en sluit dus ten nouste daarby aan. Dit volg op die vraagappélle in 6:2-3 en dien om die argument verder te voer. Daar is ernstige meningsverskil tussen Skrifverklaarders oor óf die teks as 'n vraag óf 'n imperatief verstaan moet word (Barrett 1979:137; Thiselton 2000:431-433). Ons volstaan met die punktuasie van die Griekse teks.

Waarom is die vraag 'n ironiese interrogatief? Bloot oppervlakkig gelees, dui die teks aan dat die Korintiërs oënskynlik met hulle alledaagse regsake na mense buite die gemeente gaan wat nie hoog geag word nie. Dit word deur die vraag geïmpliseer. In werklikheid bedoel Paulus presies die teenoorgestelde. Volgens die konteks is die gemeente ' $n$ eskatologies belangrike entiteit waar sake volgens ' $n$ nuwe standaard hanteer en intern tussen gelowiges besleg word, dus deur mense wat die hoogste geag word. Ironies word nou aangedui dat dit nie die geval onder die Korintiërs is nie. Hulle gaan met hulle regsake na ongelowiges, wat geen aansien in die gemeente het of behoort te hê nie. Die konflik wat per definisie in die ironie opgesluit lê, veroorsaak juis die rasionele en argumentatiewe aard van die vraag. Die funksie van die ironiese vraag word deur Paulus self verskaf: dit dien om sy lesers te beskaam (1 Kor 6:5a). Hy gaan dan voort: 'Is daar dan nie eens een wyse onder julle, wat uitspraak sal kan doen tussen sy broers nie?' (1 Kor 6:5b).

Om die ironie in die vraag te verstaan, moet die konteks van die brief as geheel in gedagte gehou word (sien hierbo). Daar was in Korinte 'n groep mense wat hulle met wêreldse wysheid besig gehou, en sodoende geestelik hoogmoedig geword het. Een van Paulus se vernaamste doelstellings met die brief was om die evangelie van die kruis te stel teenoor hierdie soort wysheid.

Soos aangedui, lê die betekenis van 'n ironiese vraag in die teenoorgestelde van wat deur die vraag geïmpliseer word. Die vraag in 1 Korintiërs 6:5b impliseer dat daar baie wyses in die gemeente was wat uitspraak kon lewer in geskille tussen broers, só het die Korintiërs immers gedink. Die betekenis van die vraag lê nou in die teenoorgestelde van hierdie implikasie: daar is nie eers een wyse onder hulle wat dit kon doen nie. Dit is hierdie realiteit wat die Korintiërs skaam moes maak: 'Maar gaan die een broer met die ander na die regbank, en dit voor ongelowiges?' (1 Kor 6:6).

Die antitetiese maar $(\alpha \lambda \lambda \alpha)$ aan die begin van die teks koppel dit aan 1 Korintiërs 6:5b as deel van 'n ironiese interrogatief. Die vraag impliseer dat gelowiges na ongelowiges gegaan het om hulle regsake te besleg. Die betekenis van die vraag lê in die teenoorgestelde hiervan: omdat die gemeente 'n eskatologies belangrike entiteit is, moes die Korintiërs hulle sake intern besleg het. Sake in die gemeente het egter so ver agteruit gegaan dat gelowiges geglo het hulle sal eerder geregtigheid vind by ongelowiges as by hulle eie medegelowiges. Dit dien tot hulle beskaming. Met sy ironiese vraag wil Paulus die praktyk probeer regstel.

\section{Slot}

In plaas daarvan om alle nie-egte vrae gewoon as retoriese vrae te beskou, is daar in hierdie artikel 'n model gebruik wat fyner onderskeiding moontlik maak. Die model is gebaseer op die taalhandelingsteorie, waarvolgens ses hoofen verskeie subkategorieë van nie-egte vrae onderskei kan word. In die model word retoriese vrae beskryf as nie-egte vrae wat stellings met groot intensiteit maak. Die model is op 1 Korintiërs 5-6 toegepas en vier van die ses hoofkategorieë (met hulle onderafdelings) is in die twee hoofstukke gevind.

Deur die verskillende soorte nie-egte vrae te onderskei en hulle funksies binne konteks te bepaal, is probeer om aan te toon hoe Paulus die vraagvorm as konstruksie gebruik het om die impak van sy kommunikasie te verhoog en die Korintiërs tot sy standpunte te oorreed. Die model bied 'n raamwerk vir die studie van vrae in al Paulus se briewe.

\section{Erkenning Mededingende belange}

Die outeur verklaar dat hy geen finansiële of persoonlike verbintenis het met enige party wat hom nadelig kon beïnvloed in die skryf van hierdie artikel nie. 


\section{Literatuurverwysings}

Argyle, A.W., 1965, An introductory grammar of New Testament Greek, Cornell University, New York.

Barrett, C.K., 1979, A commentary on the first epistle to the Corinthians, Black, Londen.

Blass, F., Debrunner, A. \& Funk, R.W., 1967, A Greek grammar of the New Testament and other early Christian literature, University Press, Chicago.

Bratcher, R.G., 1982, A translator's guide to Paul's first letter to the Corinthians: Help for translators series, UBS, New York.

Burton, E. de W., 1955, Syntax of the moods and tenses in New Testament Greek, T\&T Clark, Edinburg.

Chamberlain, W.D., 1957, An exegetical grammar of the Greek New Testament, MacMillan, New York.

Conradie, P. \& Barkhuizen, J.H., 1995, Grieks met begrip: 'n Inleidende grammatika, toegespits op die Griekse Nuwe Testament (Die Werkgroep vir Griekse Onderrig), 5de uitg., Departement Sentrale Publikasies, PU vir CHO, Potchefstroom.

Conzelmann, H., 1975, 1 Corinthians: A commentary on the first epistle to the Corinthians, transl. Hermeneia, Fortress, Philadelphia.
Fee, G.D, 1988, The first epistle to the Corinthians, Eerdmans, Grand Rapids. Goetchius, E.V.N., 1965, The language of the New Testament, Scribner, New York.

Groenewald, E.P., 1967, Die eerste brief aan die Korintiërs, NG Kerk Uitgewers, Kaapstad/Pretoria.

Lenski, R.C.H., 1963, The interpretation of St. Paul's first and second epistles to the Corinthians, Augsburg, Minneapolis.

Moulton, J.H., 1908, A grammar of New Testament Greek, T\&T Clark, Cambridge University Press, Edinburg.

Nunn, H.P.V., 1973, 'A short syntax of New Testament Greek', Cambridge, in K.A. Plank (eds.), 1987, Paul and the irony of affliction: The Society of Biblical Literature Semeia series, Scholars Press, Atlanta, Georgia.

Robertson, A.T., 1919, A Grammar of the Greek New Testament in the light of historical research, Hodder \& Stoughton, New York.

Thiselton, A.C., 2000, The first epistle to the Corinthians, A commentary on the Greek Text, NIGTC, WB Eerdmans, Grand Rapids, Michigan \& Cambridge.

Turner, N., 1963, A grammar of New Testament Greek, T\&T Clark, Edinburg.

Verster, P., 1999, 'Nie-egte vrae in die Romeinebrief: 'n Taalhandelingsperspektief', MA-verhandeling, Universiteit van die Vrystaat, Bloemfontein. 